\title{
THE IMPACT OF INTERNATIONAL INTREPRENEURSHIP ON THE DEVELOPMENT OF TRANSPORT
}

The article deals with the perspectives for the development of international entrepreneurship and the development of transport. Perspectives were determined based on research and the results of this research are presented in the article.

Keywords: International entrepreneurships, development of transport.

\section{Introduction}

The international environment is characterized by differences in its political, legal, sociocultural, economic and technological fields. Political decisions affect tariffs and taxes, laws on the protection of international investors. Economic indicators affect the level of prices, interest rates and unemployment. Technological environment influences the scientific and technological development and innovation [1 and 2].

\section{Impacts of international entrepreneurship on the development of transport}

To determine the impact of the development of international entrepreneurship on the development of transport, it is necessary to analyze the international environment and its influence on international entrepreneurship also in the transport sector. The following analyses were used in the study:

1. Analysis of tariff instruments.

2. Analysis of non-tariff instruments.

3. Analysis of the legal framework regulating the international entrepreneurship of foreign entities.

4. Analysis of trade relations formed in the international environment.

5. Analysis of the development of distribution channels in the international environment.

6. Analysis of the overall export and import of goods in international entrepreneurship.

7. Analysis of the global competitiveness of the international environment.
8. Analysis of the GDP growth and the trade balance of the international environment,

9. Analysis of other factors of international entrepreneurship in an international environment.

10. Analysis of customers in international entrepreneurship.

11. Meta-analysis.

Based on available data and carried out analyses we can evaluate each of the selected countries in terms of: commercial and political conditions, specific tariff and non-tariff instruments, customs tariffs and legislation which defines the international entrepreneurship of foreign entities, trade relations forming in the international environment, the development of distribution channels, overall export and import of goods, global competitiveness, GDP growth, trade balance and behavior of customers [3].

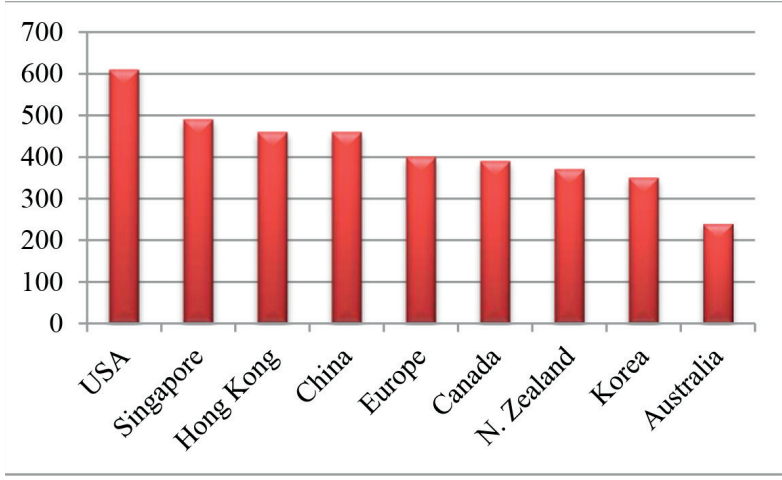

Fig. 1 The total score of countries with the most suitable conditions for international entrepreneurship (authors)

\footnotetext{
* $\quad{ }^{1}$ Bibiana Bukova, ${ }^{1}$ Eva Brumercikova, ${ }^{1}$ Pavol Kondek, ${ }^{2}$ Dusan Sojcak

${ }^{1}$ Department of Railway Transport, Faculty of Operation and Economics of Transport and Communications, University of Zilina, Slovakia

${ }^{2}$ Enersense International Oy Gallen-Kallelankatu, Pori, Finland

E-mail: bibiana.bukova@fpedas.uniza.sk
} 


\section{COMMNICOIIONS}

The total score of each country (authors)

Table 1

\begin{tabular}{|c|c|c|c|c|c|c|c|c|c|c|c|c|}
\hline Country & 1 & 2 & 3 & 4 & 5 & 6 & 7 & 8 & 9 & 10 & 11 & Total \\
\hline China & 100 & & 40 & 100 & & 90 & 80 & & & & 90 & 460 \\
\hline Hong Kong & & 90 & 50 & & & 40 & 50 & 40 & 90 & 100 & & 460 \\
\hline Singapore & 90 & 100 & 70 & & & 20 & 20 & 90 & 30 & 70 & & 490 \\
\hline Mauritius & 80 & & & & & & & & & & & 80 \\
\hline Georgia & 70 & 30 & 30 & & & & & & & & & 130 \\
\hline New Zealand & 60 & 80 & 100 & & 50 & & & & 80 & & & 370 \\
\hline T. Leste & 50 & & & & & & & & & & & 50 \\
\hline B.Darussalam & 40 & & & & & & & & & & & 40 \\
\hline Australia & 30 & & 90 & & 60 & & & & & 60 & & 240 \\
\hline Haiti & 20 & & & & & & & & & & & 20 \\
\hline Cook Islands & 10 & & & & & & & & & & & 10 \\
\hline USA & & 70 & & 90 & 90 & 80 & 90 & 80 & & 80 & 30 & 610 \\
\hline Canada & & & 80 & & 80 & 30 & 40 & & 50 & 90 & 20 & 390 \\
\hline Macedonia & & & 60 & & & & & & & & & 60 \\
\hline Rwanda & & & 20 & & & & & & & & & 20 \\
\hline Kazakhstan & & & 30 & & & & & & & & & 30 \\
\hline Belarus & & & 10 & & & & & & & & & 10 \\
\hline Ireland & & & & & & & & & 70 & & & 70 \\
\hline Germany & & & & & & & & 60 & & 50 & 40 & 150 \\
\hline Malaysia & & 50 & & 100 & 20 & & & & & & & 170 \\
\hline Korea & & 40 & & 100 & 30 & 60 & 60 & & & & 60 & 350 \\
\hline Great Britain & & & & & 70 & & & 20 & & 40 & 100 & 230 \\
\hline Norway & & 20 & & & & & & & 40 & & 70 & 130 \\
\hline Japan & & & & & 40 & 70 & 70 & 50 & & & 10 & 240 \\
\hline Russia & & & & & & 50 & & & & & & 50 \\
\hline India & & & & & & & 30 & & & & & 30 \\
\hline European Union & & & & 100 & 100 & 100 & 100 & & & & & 400 \\
\hline Mexico & & & & & & & 10 & & & & & 10 \\
\hline Oman & & & & & 10 & & & & & & & 10 \\
\hline Switzerland & & & & & & & & 100 & 20 & & & 120 \\
\hline Finland & & & & & & & & 70 & 10 & & 80 & 160 \\
\hline Sweden & & & & & & & & 10 & 60 & 10 & & 80 \\
\hline Netherlands & & & & & & & & 30 & & 30 & & 60 \\
\hline Denmark & & 60 & & & & & & & 100 & & 50 & 210 \\
\hline Spain & & & & & & & & & & 20 & & 20 \\
\hline
\end{tabular}

Source: own processing

Summary results of the carried out analyses are presented in Table 1. The scores of particular countries are from 100 to 10 according to the placement in the above-mentioned analyses.

Graphical illustration of the Top 10 countries from the total score is shown in Fig. 1. Those are countries that, based on the carried out analyses, reach the most suitable conditions for international entrepreneurship.
Figure 1 shows that the most suitable environment for international entrepreneurship is in the United States.

For an overall assessment of the USA, Singapore, Hong Kong and their comparison with Slovakia, the comparison of the following selected economic indicators is necessary: GDP growth rate, overall export and import, number of population, average monthly wage, unemployment rate and the corporate income tax. 
All data for the same time period of December 2014 are shown in Fig 2.

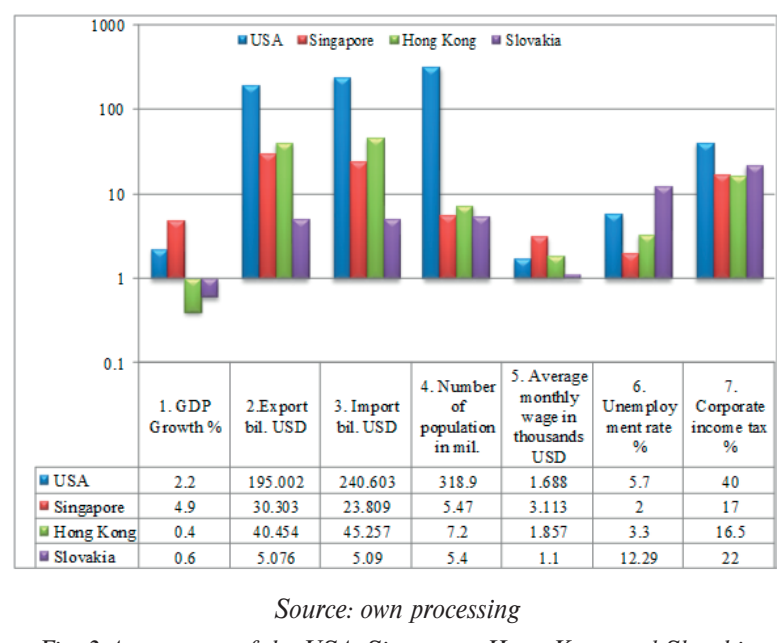

Fig. 2 Assessment of the USA, Singapore, Hong Kong and Slovakia

The following prospects of the development of international entrepreneurship and development of transport can be evaluated from the assessment of the United States, Singapore, Hong Kong and their comparison with Slovakia.

\section{Development perspectives of international entrepreneurship and the development of transport}

Prospects for entrepreneurship in the USA are the developed market with transport services which is stimulated by the size of population. Perspectives are: development of services through modernization, IT technologies, simplifying of purchase, building self-service systems and eliminating intermediaries in trade.

Prospects for entrepreneurship in Singapore are international investments in the development of services or production. A low unemployment rate and a high average salary of the population increase the demand for quality products and transport services. Perspective are products with the possibility of original and tailormade products through mass customization [4].

Prospects for entrepreneurship in Hong Kong are investment in production and services. The market of manufacturers in Hong Kong is popular due to producing cost-effective and quality products with quick delivery time resulting from a rapid production rate and eliminating intermediaries in the hierarchy.

Despite the fact that the USA maintains a position of economic power, Asian countries are "progressing" in favorable conditions for international entrepreneurship. Low import tariffs, a simplified process of starting a business, an established system to protect investors, trade freedom, tax burden, bureaucracy, established bilateral relations and the low costs of labor and materials allow Asian countries to create the most suitable environment for international entrepreneurship. Europe also provides a suitable environment for international entrepreneurship, however, it protects its internal food market, which to a large extent, has consisted of imported food in recent years.

Prospects of international entrepreneurship are in the phase of the development of enhancement and modernization of transport services such as simplification of purchase and removing intermediaries. Further prospects are in increasing export through the production of quality, innovative and cost-efficient products with short delivery time and the production of original and tailormade products through mass customization [5].

\section{Conclusion}

The international environment is constantly evolving and changing, regions that were among developing regions begin to evolve and the financial inequality deepens. The international environment contains entities with the availability of large amounts of capital and, on the other hand, "poor" environment with low living standards. Products are designed to meet the needs of consumers - customers. Several experts point to major changes in behavioral patterns of customers, which ultimately has an impact on the competitive forces on the global market. Ongoing trends, particularly those relating to the use of digital technologies also bring threats and opportunities for manufacturers as well as carriers [6 and 7].

\section{Acknowledgment}

This paper was supported by the VEGA Agency, Grant No. $1 / 0701 / 14$ "The impact of the railway freight transport market liberalization on the social transport costs".

\section{References}

[1] DROZDZIEL, P., KOMSTA, H., KRZYWONOS, L.: Repair Costs and the Intensity of Vehicle use. Transport Problems, vol. 8, No. 3, 2013, ISSN 18960596.

[2] BRUMERCIK, F., DANKO, R.: Transport Application of Hybrid Simulation. Communications - Scientific Letters of the University of Zilina, No. 2, 2014, pp. 20-23, ISSN 13354205. 


\section{COMMNICOIIONS}

[3] DROZDZIEL, P., KOMSTA, H., KRZYWONOS, L.: An Analysis of Unit Repair Costs as a Function of Mileage of Vehicles in a Selected Transport Company. Transport Problems. vol. 9, No. 4, 2014, ISSN 18960596.

[4] PRUSA, P., TILKERIDIS, D.: Possibilities of Logistics Policy Improvement. Promet - Traffic \& Transportation, vol. 21, No. 21, 2009.

[5] LIZBETIN, J., CAHA, Z.: Methodology for the Calculation of Functional Elements in Warehouses of Public Intermodal Logistics Centers. Nase More, vol. 62, 2015, ISSN 04696255.

[6] BRUMERCIK, F., TOMASIKOVA, M., NIEOCZYM, A.: Epicyclic Gear Train Synthesis, Communications - Scientific Letters of the University of Zilina, No. 3, 2015, pp. 47-50, ISSN 1335-4205.

[7] BUKOVA, B., BRUMERCIKOVA, E., KOLAROVSZKI, P.: Spedition and Logistics (in Slovak), Wolters Kluwer, 2014, ISBN 978-809168-074-8. 